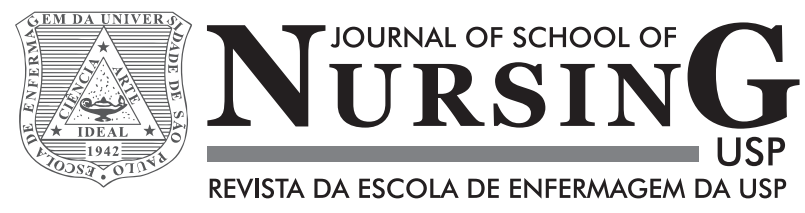

\title{
Assistive technology for visually impaired women for use of the female condom: a validation study*
}

\author{
Tecnologia assistiva para mulheres com deficiência visual acerca \\ do preservativo feminino: estudo de validação \\ Tecnología asistiva para mujeres con deficiencia visual acerca \\ del preservativo femenino: estudio de validación
}

Luana Duarte Wanderley Cavalcante ${ }^{1}$, Giselly Oseni Barbosa Oliveira ${ }^{2}$, Paulo César de Almeida ${ }^{3}$, Cristiana Brasil de Almeida Rebouças ${ }^{4}$, Lorita Marlena Freitag Pagliuca ${ }^{5}$

\footnotetext{
* Extracted from the thesis "Validação de tecnologia assistiva para a deficiente visual: utilização do preservativo feminino," Graduate Nursing Program, Universidade Federal do Ceará, 2013.

${ }^{1}$ Doctorate Nursing Student, Universidade Federal do Ceará, Fortaleza, CE, Brazil.

${ }^{2}$ PhD Professor, Universidade Federal do Ceará, Fortaleza, CE, Brazil.

${ }^{3} \mathrm{PhD}$ Professor, Nursing Department, Universidade Federal do Ceará, Fortaleza, CE, Brazil.
}

\begin{abstract}
Objective: To validate assistive technology for visually impaired women to learn how to use the female condom. Method: a methodological development study conducted on a web page, with data collection between May and October 2012. Participants were 14 judges; seven judges in sexual and reproductive health (1st stage) and seven in special education (2nd stage). Results: All items have reached the adopted parameter of $70 \%$ agreement. In Stage 1 new materials were added to represent the cervix, and instructions that must be heard twice were included in the $2^{\text {nd }}$ stage. Conclusion: The technology has been validated and is appropriate for its objectives, structure / presentation and relevance. It is an innovative, low cost and valid instrument for promoting health and one which may help women with visual disabilities to use the female condom.
\end{abstract}

\section{DESCRIPTORS}

Visually Impaired Persons; Technology; Condoms, Female; Sexually Transmitted Diseases; Public Health Nursing; Validation Studies.
Correspondence Addressed to:

Luana Duarte Wanderley Cavalcante

Rua Alexandre Baraúna, 1115 - Rodolfo Teófilo

CEP 60430-160 - Fortaleza, CE, Brasil

E-mail: luana_dw@hotmail.com
Received: 08/06/2014

Approved: 11/07/2014 


\section{INTRODUCTION}

Given the limited assistance dedicated to the visually impaired in relation to sexuality, it is worth noting the occurrence of sexually transmitted diseases (STDs) in this specific group $^{(1)}$. According to the Ministry of Health $(\mathrm{MOH})$ in Brazil, there are about 10 to 12 million new STDs cases per year, and the evidence of STDs history among sexually active women between 15 and 64 years is $56.5 \%{ }^{(2)}$.

Studies show that the Human Immunodeficiency Virus (HIV)/AIDS poses a significant threat to Disabled Persons (DP) worldwide ${ }^{(3)}$. Research in Uganda shows that $38 \%$ of women and $35 \%$ of men with disabilities reported having had an STD at one time ${ }^{(4)}$. However, both internationally and in Brazil, little is known about the estimated rates of STDs and HIV/AIDS in DP.

In addition to the denial of sexuality for these individuals, certain factors such as poverty, misinformation and stigma contribute to social marginalization and greater exposure to STDs. The researchers emphasize that the increase in this risk also comes from misinformation and lack thereof on the part of the visually DP, health professionals, and society, which makes them more susceptible to this risk $^{(1)}$. In this context, adolescents with visual impairments showed the same sexual development characteristics of their age group and showed lack of knowledge about contraception and STDs ${ }^{(5)}$.

Because of their condition, the visually DP experiences difficulties in access to information on health, particularly with regard to sexual and reproductive health which require a different approach ${ }^{(6)}$. The lack of appropriate information in the area of sexuality contributes to the increased vulnerability of visually DP in relation to $\mathrm{STDs}^{(7)}$. Thus, there is the need for nursing initiatives in the prevention of STDs focusing on visually DP, as well as the urgency to develop methods and materials in this subject and make them accessible to this group.

Among them, there is Assistive Technology (AT). This is a term used to identify the set of resources and services that provide or expand functional abilities of DP and the elderly. The goal is to provide greater independence, better quality of life and social inclusion through the expansion of communication, mobility, their environmental control, skills, work, and integration with the family and society ${ }^{(8)}$.

An AT was developed that simulates the vaginal canal for women with visual impairment so that from adolescence they could learn how to use the female condom. Such technology includes a model of the vaginal canal, its assembly instructions and the instructions for use of the female condom. The model was built with sponges and rubber bands and guidelines for the use of female condoms were based on technical standards published by the Ministry of Health ${ }^{(9)}$ and adapted for visually impaired customers ${ }^{(10)}$.

The choice of the female condom is justified with a view to women's lack of knowledge about the subject and also the issue of gender implicit in disclosure and design, as it prevails over a man's decision in choosing the method, thereby requiring the woman to be more involved in this process. A study found that while women are interested in trying the female condom, there are still obstacles such as lack of knowledge about its use, poor access to the method and especially the fear of bothering their partner by recommending a new means of prevention ${ }^{(11)}$.

Despite the poor acceptance of the female condom, the technology of this study aims to encourage its use, as it is a method that offers dual protection and greater autonomy to the woman. The technology is innovative and offers women the opportunity to choose which contraceptive method to use.

The relevance of this study is to obtain a technology that refers to sexual and reproductive health, validated by judges in this theme and in the area of special education. In addition, there is the possibility of health information disclosure on the use of the female condom on the website, ensuring that a large number of visually impaired can remotely access the health knowledge.

The AT may contribute to decrease risky behaviors of visually impaired people, and this initiative may encourage health professionals, especially nurses, to study more health education including about the visually impaired and their sexuality. Nurses can also use the technology in nursing consultation to address family planning and STD prevention.

The use of AT by teachers in teaching young students with visual impairments is also important with the aim of presenting an alternative prevention against STDs and unwanted pregnancies for women with visual impairment from adolescence, and so they do not start adopting risky behaviors but develop safe sexual practice instead. However, before use of material resources for this group, it is necessary to deepen understanding as to its effectiveness and efficiency ${ }^{(12)}$.

Before reduced availability of resources for health education and prevention of risky behaviors related to sexual and reproductive health for the visually impaired in this context, this study may contribute to the promotion of sexual and reproductive health for women with visual impairments, as well to encourage the creation of other easily accessible and affordable technologies by other professionals.

Thus, the objective was to validate the Assistive Technology Made to learn how to use the female condom for women with visual impairment by expert judges in sexual and reproductive health and with specialized education for DP.

\section{METHOD}

This is a methodological development study. An adaptation of the criteria set out in Pasquali's ${ }^{(13)}$ Model of Psychological Test Construction was made for review by judges, based on a trial conducted by a group of experts with experience in the field, analyzing if the content is correct and appropriate to what is proposed.

The study was developed on a web page (www.labcomsaude.ufc.br) of the Communication Health Lab (LabCom_Saúde) of the Nursing Department of the Federal University of Ceará (UFC), a place that brings together equipment and infrastructure needed for research. Data collection took place between May and October 2012. 
The study sample consisted of seven judges with backgrounds in sexual and reproductive health content and seven judges with backgrounds in pedagogical aspects in the field of special education. For the selection of participants, we used intentional non-probability sampling.

The search for the judges in sexual and reproductive health content was done by searching with keywords: $f e-$ male condom and sexual and reproductive health at Curriculum Lattes and evaluations thereof through publications on the subject. The judges were contacted by using their e-mail address or by presenting them with a letter of invitation. For judges in special education, the search was done through visits to visually DP educational institutions or by the indication/recommendation of the judges themselves.

The criteria for participation and choice of sexual and reproductive health judges were: they must have at minimum a $\mathrm{PhD}$ in the specific area and/or areas related to sexual and reproductive health and have developed academic activities in the area over the last three years; for judges in special education, they must have at minimum a title of expertise in the field of special education and/or work in the area.

Data collection was performed in two stages. The first was the validation of the AT by the judges in sexual and reproductive health, using a validated instrument in this study. The items of the instrument were divided into three groups: 1 . objectives; 2 structure and presentation; and 3. relevance. The answers followed the Likert scale, with the following description: fully adequate (5), appropriate (4), cannot answer (3), inappropriate (2) and fully inappropriate (1). This description was performed in order to identify the necessary corrections to the technology.

In the second stage, validation of the AT by the judges in special education, the assembly instructions and use of the technology were audio recorded with MP3 format and made available on the internet at the LabCom_Saúde page (www.labcomsaude.ufc.br) only to the judges. The availability of the AT on the Internet has been used in order to simulate the desired future viability for visually DP. Thus, it is necessary that the judges evaluate the technology with the same presentation that will be made available for users with visual impairments.
At this stage an instrument developed in previous research $^{(14)}$ was also used following the Likert scale. The items of the instrument were divided into two blocks: 1 . objectives; and 2. structure and presentation.

To compare similarities and differences, we proceeded to read and analyze the suggestions of individual judges. The suggested adjustments which were considered pertinent were incorporated into the technology. It is worth noting that most of the suggestions made by the evaluators were fully accepted, with no need for re-evaluation by the judges.

Data were quantitatively analyzed by organizing and processing in Excel 2000. The adequacy of behavioral representation of the items was calculated. This refers to the calculated statistical value corresponding to the arithmetic mean of the item considered by the judges. According to the tools, the answer options 1, 2, 3, 4 and 5 were grouped as follows: 1 and 2 (score $=-1), 3$ (score $=0)$, and 4 and 5 $($ score $=+1)$, where the response of each judge could vary from -1 to +1 . The concordance index $(\mathrm{CI})$ was defined as $\left(f^{*} \mathrm{i}\right) / \mathrm{n}$, where $\mathrm{f}=$ frequency, $\mathrm{i}=-1,0$ or 1 and $\mathrm{n}=$ number of judges $(n=7)$. The closer this ratio is to 1.0 , the greater the agreement that the item is relevant ${ }^{(12)}$. Validated items that obtained a concordance index greater than or equal to $70 \%(0.7)$ were considered.

This project was approved by the Ethics Committee of UFC research under protocol number 38/12, respecting the ethical principles for research involving human subjects.

\section{RESULTS}

\section{Stage 1 - Validation of the Assistive Technology by JUDGES IN SEXUAL AND REPRODUCTIVE HEALTH}

Participants were seven judges (J1 to J7): Two from the attendance/assistance area and five teachers. Six were graduated in nursing and one in biosciences. The training ranged between 6 and 40 years, and the duration of professional activities in the current institution ranged between one and 29 years.

Table 1 shows the levels of agreement between judges according to each block and item.

Table 1 - Levels of agreement among the judges of sexual and reproductive health in accordance with the blocks and items - Fortaleza, CE, 2013.

\begin{tabular}{|c|c|c|c|c|}
\hline Items & +1 & $\mathbf{0}$ & -1 & IC \\
\hline \multicolumn{5}{|l|}{ Objectives } \\
\hline 1.1 Depicts the form of the vaginal canal & 6 & 0 & 1 & 0.71 \\
\hline 1.2 Depicts the length of the vaginal canal & 6 & 1 & 0 & 0.85 \\
\hline 1.3 Portrays the elasticity of the vaginal canal & 6 & 1 & 0 & 0.85 \\
\hline 1.4 The model allows for inserting the female condom by herself & 6 & 0 & 1 & 0.71 \\
\hline 1.5 Facilitates learning about female condom insertion & 7 & 0 & 0 & 1.00 \\
\hline 1.6 The model facilitates understanding of the female anatomy & 6 & 0 & 1 & 0.71 \\
\hline \multicolumn{5}{|l|}{ Structure and Presentation } \\
\hline 2.1 The material that makes up the model is easily accessible & 7 & 0 & 0 & 1.00 \\
\hline 2.2 Contain instructions considered essential to use the female condom & 7 & 0 & 0 & 1.00 \\
\hline
\end{tabular}




\begin{tabular}{|c|c|c|c|c|}
\hline Items & +1 & $\mathbf{0}$ & -1 & IC \\
\hline 2.3 The instructions are scientifically correct & 7 & 0 & 0 & 1.00 \\
\hline 2.4 The instructions are in clear and understandable terms & 6 & 0 & 1 & 0.71 \\
\hline 2.5 The instructions are current & 7 & 0 & 0 & 1.00 \\
\hline 2.6 It is free from discrimination or prejudice & 7 & 0 & 0 & 1.00 \\
\hline 2.7 There is a logical sequence of the proposed content & 7 & 0 & 0 & 1.00 \\
\hline \multicolumn{5}{|l|}{ Relevance } \\
\hline 3.1 Encourages change of attitude and practice & 5 & 2 & 0 & 0.71 \\
\hline 3.2 Facilitates health education in different contexts (school, home, hospital and outpatient) & 7 & 0 & 0 & 1.00 \\
\hline
\end{tabular}

According to Table 1 , it was found that all were considered suitable items $(\mathrm{CI} \geq 70 \%)$. However, some judges suggested changes to the technology that will be presented below, according to each block.

Block 1 refers to the objectives, which are determined by the purposes, goals or end use which they wish for in using the technology. It was observed that from the 42 responses, 37 (88\%) were appropriate, only three (7.3\%) were inadequate and two (4.7\%) could not answer. Thus, the technology was considered appropriate as to the proposed objectives.

In this block, items $1.1,1.4$ and 1.6 which received a concordance index of 0.71 according to Table 1 , gave an inadequate response. In section 1.1, which refers to the shape of the vaginal canal, J1 and J5 stated that the width and length of the channel varies according to each woman and according to the state of arousal, and J2 suggested carrying out health education with the technology being addressed by conversation; that there is diversity among women and stretching of the vaginal canal. This suggestion was included in the instructions and is an important strategy for explaining the female anatomy.

Another item that had inadequate response was 1.4, which addresses condom insertion in the model. J5 reported that the open side of the model may impede the introduction/insertion of the condom and suggested sewing it, but this practice hinders the construction of the model which doesn't fit with the goal. Also, this was the only judge who dealt with this aspect. Figure 1 illustrates the model of the vaginal canal.

Item 1.6 refers to the model to facilitate understanding of the female anatomy also received an inappropriate rating. Three judges (J5, J6 and J7) reported the same issue: missing the cervix in the vaginal canal model. J7 suggested using crumpled paper, "a ball of paper," to represent it. This suggestion was incorporated into the female condom model and we used a piece of a plastic bag for the paper to stay firm in the model. Thus, the female condom model continues with simple, cheap and easy to assemble materials.

Items 1.2 and 1.3 received only appropriate valuations, however they also received suggestions. In section 1.2 which addressed the length of the vaginal canal model, J2 said that it should be lower. This suggestion was accepted with the placement of a paper ball inside the vaginal canal, reducing

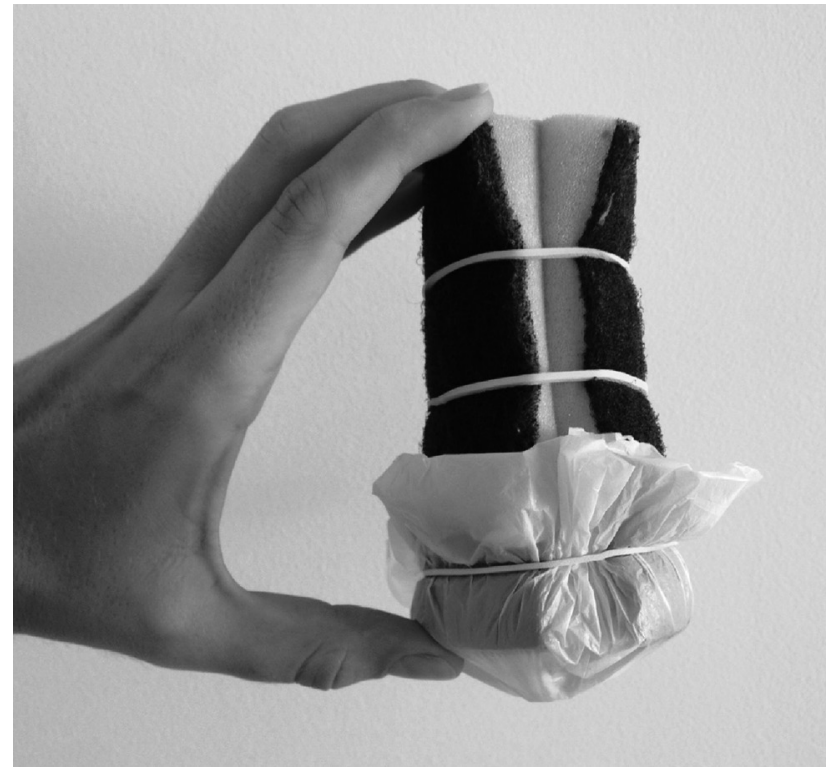

Figure 1 - Model of the vaginal canal - Fortaleza, CE, 2013.

its length. In relation to item 1.3 which referred to the elasticity of the model, J1 reported that by putting two fingers inside, it was able to expand due to the presence of elastic alloys. However, J2 ruled that the model has a different elasticity of the vaginal canal and this fact can leave the inner ring of the condom restricted in the model. Nevertheless, the adaptation with the "ball of paper" allows the inner ring to snap into the bottom of the model, between sponges and a plastic bag.

Block 2 refers to the structure and presentation that are determined by way of presenting the technology. It involves the overall organization, structure, presentation strategy, consistency and sufficiency. It was observed that of the 49 responses, 48 (98\%) were appropriate, and only one (2\%) were inadequate (in section 2.4); the only block 2 with a concordance index of 0.71 , according to Table 1 . Thus, the technology was considered/deemed appropriate for the structure and presentation.

In item 2.4 which refers to the clarity of the instructions, J5 said it should be added that the female condom consists of a larger fixed ring and a smaller movable ring at the bottom of the condom. This suggestion was incorporated into the technology, along with other collaborations from $\mathrm{J} 5$ and J7, which was to include the statement: touch 
the entire length of the condom to identify its component parts. These suggestions are also suitable for item 2.2 (essential instructions), however this had a suggestion for assembly instructions which proposed to add that the two sponges should stay side by side, considering the sponge texture and that the instructions should exhibit the two parts of the sponges with different textures. This suggestion was also considered relevant and necessary for technology improvements.

Block 3 refers to the relevance, the feature that assesses the degree of significance of technology. It was found that of the 14 responses, $12(85.7 \%)$ were adequate and two $(14.3 \%)$ could not answer. No response was inadequate in this block and there were no suggestions, so the technology was considered appropriate.
Stage 2 - Validation of the Assistive Technology by JUDGES IN SPECIAL EDUCATION

In this step, there were also seven judges who participated in reviewing the technology (J8 to J14): all special education teachers, four graduated in pedagogy, one in language arts, one in biology and physical education. The training ranged from nine to 27 years and the duration of professional activities in the current institution was between four months and 17 years. Among the subjects, it is noteworthy that $\mathrm{J} 8$ is totally blind and J14, despite working only four months ago with visually $\mathrm{DP}$, has five years of experience in teaching motor, multiple and mental skills to DP.

Table 2 presents the concordance rates between special education judges according to each block and item.

Table 2 - Concordance rates between special education judges according to the blocks and items - Fortaleza, CE, 2013.

\begin{tabular}{|c|c|c|c|c|}
\hline Items & +1 & $\mathbf{0}$ & -1 & IC \\
\hline \multicolumn{5}{|l|}{ Objectives } \\
\hline 1.1 The technology helps and encourages learning & 7 & 0 & 0 & 1.0000 \\
\hline 1.2 It encourages autonomy, being self-instructional & 7 & 0 & 0 & 1.00 \\
\hline 1.3 The technology is the at the level of knowledge of the target audience & 7 & 0 & 0 & 1.00 \\
\hline 1.4 It arouses interest and curiosity & 7 & 0 & 0 & 1.00 \\
\hline 1.5 It emphasizes the importance of content to the target audience & 7 & 0 & 0 & 1.00 \\
\hline \multicolumn{5}{|l|}{ Structure and Presentation } \\
\hline 2.1 It is adapted to the target audience & 7 & 0 & 0 & 1.00 \\
\hline 2.2 It is appropriate to the age range proposed & 6 & 1 & 0 & 0.85 \\
\hline 2.3 The technology does not demonstrate any kind of discrimination or prejudice & 7 & 0 & 0 & 1.00 \\
\hline 2.4 The form and presentation of technology is appropriate & 6 & 0 & 1 & 0.71 \\
\hline 2.5 The material of the technology is appropriate (audio, sponge, alloys) & 7 & 0 & 0 & 1.00 \\
\hline
\end{tabular}

According to Table 2, we observed that all items were considered adequate $(\mathrm{CI} \geq 70 \%)$. However, some judges have also suggested changes in technology, as presented below.

In block 1 (Objectives), all 35 responses were appropriate and obtained the maximum rate of agreement. Therefore, the technology was considered appropriate as to the proposed objectives. In item 1.5 which addresses the importance of the content, J11 suggested adding information that emphasized the importance of using the female condom in the instructions. Thus, the following phrase was added: Remember: The female condom offers dual protection because it is an effective method of contraception and STD prevention.

In block 2, it is observed that the responses 35,33 (94.2\%) were efficient, which makes the technology suitable for special education judges on the structure and presentation.

According to Table 2, only item 2.4 (which refers to the form and production of the technology) obtained a concordance index of 0.71 . This received an inadequate response and therefore some suggestions. The first was related to the audio. It is worth recalling that the technology was recorded on audio and posted on the Internet for the special education judges to evaluate. J9, J10 and J12 reported that the length of time between instructions is too short in the audio which caused difficulty in following the guidelines. Thus, they stressed that more time between instructions is needed for it to be effective and for avoiding doubt about the assembly and use of the female condom. This suggestion was considered relevant and will be implemented in the new recording technology.

J11 proposed a second suggestion that the user should initially listen to the instructions and then hear them a second time while reproducing the technology (model). J9 and $\mathrm{J} 10$ also emphasized the need to repeat the entire procedure. This suggestion was added in the installation instructions for using the female condom. The judges J9, J10, J13 and J14 made a third suggestion: describe the exact location where the female condom should be inserted. In addition, $\mathrm{J} 9$ warned that the implementation instructions failed to mention that the ball of paper represents the cervix. Given the relevance, these suggestions were incorporated into the technology.

\section{DISCUSSION}

It is important that health education and the content of the communication be built in an accessible format to ensure that users with disabilities are fully able to obtain resources and use them whenever necessary ${ }^{(15)}$. The visually DP requires specific resources to facilitate the acquisition of 
knowledge, with the aim of complementing the process of teaching and learning ${ }^{(16)}$.

It is recommended that listening materials are used together with tactile materials, strategies with group interaction and an inclusive approach, enabling that learning facilities are accessible to all ${ }^{(17)}$. Using the technology of this study involves touch and listening together with the dialogue between facilitator and women with visual impairment, which can make health education more effective.

The educational materials for visually DP should authentically represent what we aim to build, resembling as much as possible the original model and should be simple and easy to handle ${ }^{(18)}$. The handling of materials allows for tactile perception, favoring increased dexterity of touch and the assimilation of more precise form of content by the visually impaired, making these resources of essential importance for their education ${ }^{(10)}$.

According to a previous study ${ }^{(18)}$, the material should be resistant to frequent tactile exploration, so as not to damage easily and also should not generate disgust. According to the authors, it is also important that these materials are made up of different textures to highlight all component parts and to allow for better identification, exploring contrasts, for example: smooth and rough; thin and thick; soft and hard. Furthermore, they must display contrasting colors, to make it attractive to those who have reduced vision and those who aren't visually impaired, and it should be pleasing to the touch for those with total blindness, therefore, material which is suitable for all ${ }^{(18)}$. There was concern about making the technology in this study as close to reality as possible in order to promote more concrete learning and make it appropriate for the visually DP so that it was practical and provides significant use.

Given this scenario, health services should be prepared to provide health education that includes special education concepts as well as resources and methods adapted for the visually $\mathrm{DP}^{(17)}$. It is important for nurses to develop inclusive educational materials based on the concept of universal design so that they are accessible to all people ${ }^{(15)}$. However, this situation is still short of what is expected. Therefore, to achieve effective health education at the health center, school, or in another environment, it is necessary to have educational materials and methods adapted for the visually impaired. The technology of this study is an educational resource that can sensitize women with visual disabilities to use the female condom.

The female condom is an alternative that in addition to facilitating its use in negotiation with their partner, provides double protection; it protects against sexually transmitted infections/diseases and against unwanted pregnancy ${ }^{(19)}$. Thus, it is important to encourage the use of the female condom and disseminate knowledge about it, addressing its operating instructions in order to enable women to exercise care for their sexual and reproductive health, thereby contributing to their autonomy ${ }^{(6)}$.

The study revealed that despite the limited supply of female condoms in public health services, there are initiatives to expand it and to make it a more appropriate method anatomically, and to improve the appearance and reduce its price. According to the same study, by increasing its availability and use there needs to be training and sensitization conducted for health professionals, especially for those that are at basic units in order to make the female condom a real alternative for women ${ }^{(19)}$. Therefore, the technology presented in this study will help to make the female condom more known and encourage its use, as well as to promote social inclusion.

The literature states that currently the technological resources are increasingly present in daily life, facilitating access to information and thereby fostering learning, interpersonal relationships and leisure. It is therefore critical that these resources constitute a means of social inclusion so that all people can use them independently, and that such resources need to be accessible ${ }^{(20)}$. The purpose of this study is to make the technology available on the internet to facilitate access to all people, and is an important form of disclosure. Thus, the AT of this study is fundamental in health education for visually DP, as it contributes to their autonomy and social inclusion.

It is essential that people with disabilities feel included in society and can access various content on the Internet ${ }^{(20)}$. Given this scenario's benefits, it is extremely important that nursing develops project promotion and health education focused on visually DP by accessing the knowledge gap so that the various and specific areas of knowledge are considered ${ }^{(14)}$.

\section{CONCLUSION}

The AT was considered appropriate by the judges in sexual and reproductive health. The suggestions were accepted to modify the model of the vaginal canal by adding the representation of the cervix and thus include new materials such as paper and plastic. New, clearer and more objective instructions were included in the recording to describe how to assemble the vaginal canal model. In the instructions for use, more details were included to describe all parts of the female condom and it was added that the user must touch/feel the entire length of the model to identify these parts.

The AT was also deemed appropriate by the judges in special education. Among the relevant suggestions incorporated were that the user must listen to all the instructions given and then to hear them a second time while touching/ assembling the model. In addition, the description of the exact location where the female condom should be inserted was included and the information that the ball of paper is the cervix. In the recorded audio, the time interval between the instructions must be longer.

This AT may be a health promotion tool, helping women with visual disabilities to learn how to use the female condom and avoid an unwanted pregnancy or STD infection. It is also expected that the AT can collaborate to reduce risky behavior of people with visual impairments, as it provides knowledge about the female anatomy and the use of the female condom in a creative, interactive and effective way. 
When the AT is available on the website it may be constructed and used through the instructions by health professionals, especially nurses, during nursing consultations and during health education activities. It can also be accessed and used by special education teachers in teaching young people with visual impairments, but can also be used by people without vision impediment. As it is made of simple materials and is easy to construct, it is also possible that the
AT can be used by the family, especially parents, of visually DP for sex education.

This study may encourage nurses to create and validate materials aimed at promoting the health of visually DP and to conduct comprehensive health education for visually DP and their sexual health. Among the future prospects is the implementation of the AT for a statistically significant group of women with visual impairment.

\section{RESUMO}

Objetivo: Validar tecnologia assistiva para mulheres com deficiência visual aprenderem a utilizar o preservativo feminino. Método: Estudo de desenvolvimento metodológico, realizado em página da web, com coleta de dados entre maio e outubro de 2012. Participaram 14 juízes, sendo sete juízas em saúde sexual e reprodutiva (1ª etapa) e sete em educação especial (2a etapa). Resultados: Todos os itens atingiram o parâmetro adotado de $70 \%$ de concordância. $\mathrm{Na} 1^{\text {a }}$ etapa foi acrescentada a representação do colo do útero com novos materiais e na $2^{\mathrm{a}}$ incluiu-se que as instruções devem ser ouvidas duas vezes. Conclusão: A tecnologia foi validada e está adequada quanto aos objetivos, estrutura/apresentação e relevância. É um instrumento de promoção da saúde válido, inovador e de baixo custo, que poderá auxiliar mulheres com deficiência visual a utilizar o preservativo feminino.

\section{DESCRITORES}

Pessoas com Deficiência Visual; Tecnologia; Preservativos Femininos; Doenças Sexualmente Transmissíveis; Enfermagem em Saúde Pública; Estudos de Validação.

\section{RESUMEN}

Objetivo: Validar la tecnología asistiva a fin de que las mujeres con discapacidad visual aprendan a utilizar el preservativo femenino. Método: Estudio de desarrollo metodológico, llevado a cabo en página web, con recolección de datos entre mayo y octubre de 2012. Participaron 14 jueces, siendo siete juezas en salud sexual y reproductiva ( $1^{\text {a }}$ etapa) y siete en educación especial ( $2^{\text {a }}$ etapa). Resultados: Todos los puntos alcanzaron el parámetro adoptado del $70 \%$ de concordancia. En la $1^{\text {a }}$ etapa se añadió la representación del cuello uterino con nuevos materiales y en la $2^{\text {a }}$ se incluyó que las instrucciones se las debe oír dos veces. Conclusión: La tecnología fue validada y está adecuada en cuanto a sus objetivos, estructura/presentación y relevancia. Es un instrumento de promoción de la salud válido, innovador y de bajo costo, que podrá auxiliar a las mujeres que tienen discapacidad visual a utilizar el preservativo femenino.

\section{DESCRIPTORES}

Personas con Daño Visual; Tecnología; Condones Femininos; Enfermedades de Transmisión Sexual; Enfermería en Salud Pública; Estudios de Validación.

\section{REFERENCES}

1. Brasil. Ministério da Saúde; Secretaria de Vigilância em Saúde, Departamento de DST, Aids e Hepatites Virais. Pesquisa de Conhecimentos, Atitudes e Práticas na População Brasileira de 15 a 64 anos 2008. Brasília; 2011.

2. Sousa FS, Baptista RS, Coura AS, França EG, Pagliuca LMF, França ISX. Sexualidade das pessoas com deficiência (PcD) e a vulnerabilidade à aids: revisão sistemática de literatura. Online Braz J Nurs [Internet]. 2009 [citado 2012 abr. 30]; 8(3). Disponível em: http://www.objnursing.uff.br/index.php/nursing/article/view/j.1676-4285.2009.2566/565

3. Groce N. Levantamento mundial sobre HIV/Aids e deficiências [Internet]. Connecticut; 2004. [citado 2012 abr. 12]. Disponível em: http:// cira.med.yale.edu/global survey

4. Mulindwa IJ. Study on reproductive health and HIV/AIDS among persons with disabilities in Kampala, Katakwi and Rakai Districts [Internet]. Kampala (UG): DWNRO; 2003 [cited 2012 Apr 30]. Available from: http://www.aidsfreeworld.org/Our-Issues/Disability/ /media/3A9C D534F627486091B5BDDBC35C2F8A.pdf

5. Bezerra CP, Pagliuca LMF. The experience of sexuality by visually impaired adolescents. Rev Esc Enferm USP [Internet]. 2010 [cited 2013 Jan 20];44(3):578-83. Available from: http://www.scielo.br/pdf/reeusp/v44n3/en_05.pdf

6. Wanderley LD, Barbosa GOL, Rebouças CBA, Oliveira PMP, Pagliuca LMF. Sexualidade, DST e preservativo: comparativo de gênero entre deficientes visuais. Rev Enferm UERJ. 2012;20(4):463-9.

7. Paula AR, Sodelli FG, Faria G, Gil M, Regen M, Meresman S. Pessoas com deficiência: pesquisa sobre a sexualidade e vulnerabilidade. Temas Desenvolv. 2010;17(98):51-65.

8. Bersch R. Introdução à tecnologia assistiva [Internet]. 2008 [citado 2009 set. 8]. Disponível em: http://www.assistiva.com.br/Introducao_Tecnologia_Assistiva.pdf

9. Brasil. Ministério da Saúde. Caderneta de Saúde da Adolescente. Brasília; 2009 [citado 2010 maio 13]. Disponível em: http://portal.saude. gov.br/portal/arquivos/pdf/cardeneta_meninas.pdf

10. Cavalcante LDW, Barbosa GOL, Oliveira PMP, Rebouças CBA, Pagliuca LMF. Assistive technology for visually impaired women: use of the female condom - descriptive study. Online Braz J Nurs [Internet]. 2013 [cited 2012 May 13];12(3):534-45. Available from: http://www. objnursing.uff.br/index.php/nursing/article/view/3992/html 
11. Oliveira JCP, Wiezorkievicz AM. O conhecimento das mulheres sobre o uso do preservativo feminino. Ágora. 2010;17(1):79-84.

12. Oliveira MS, Fernandes AFC, Sawada NO. Manual educativo para o autocuidado da mulher mastectomizada: um estudo de validação. Texto Contexto Enferm. 2008; 17(1):115-23.

13. Pasquali L. Instrumentação psicológica: fundamentos e práticas. Porto Alegre: Artmed; 2010.

14. Oliveira PMP, Pagliuca LMF. Assessment of an educational technology in the string literature about breastfeeding. Rev Esc Enferm USP [Internet]. 2013 [cited 2012 June 23];47(1):205-12. Available from: http://www.scielo.br/pdf/reeusp/v47n1/en_a26v47n1.pdf

15. Carvalho AT, Silva ASR, Fernandes AFC, Pagliuca LMF. Health education for the blind: evaluation of accessibility of an inclusive online course. Creat Educ. 2014;5(16):1559-66.

16. Oliveira PMP, Pagliuca LMF, Carvalho ALRF. Cultural adaptation of educative technology in health: string literature with a focus on breastfeeding. Texto Contexto Enferm. 2014;23(1):134-41.

17. Pagliuca LMF, Cezario KG, Mariano MR. A percepção de cegos e cegas diante das drogas. Acta Paul Enferm 2009;22(4):404-11.

18. Sá ED, Campos IM, Silva MBC. Atendimento educacional especializado: deficiência visual. Brasília: Cromos; 2007.

19. Kalckmann S, Farias N, Carvalheiro JR. Avaliação da continuidade de uso do preservativo feminino em usuárias do Sistema Único de Saúde em Unidades da Região Metropolitana de São Paulo, Brasil. Rev Bras Epidemiol. 2009;12(2):132-43.

20. Silva S. Acessibilidade digital em ambientes virtuais de aprendizagem. Rev GEINTEC. 2012;2(3):245-54. 